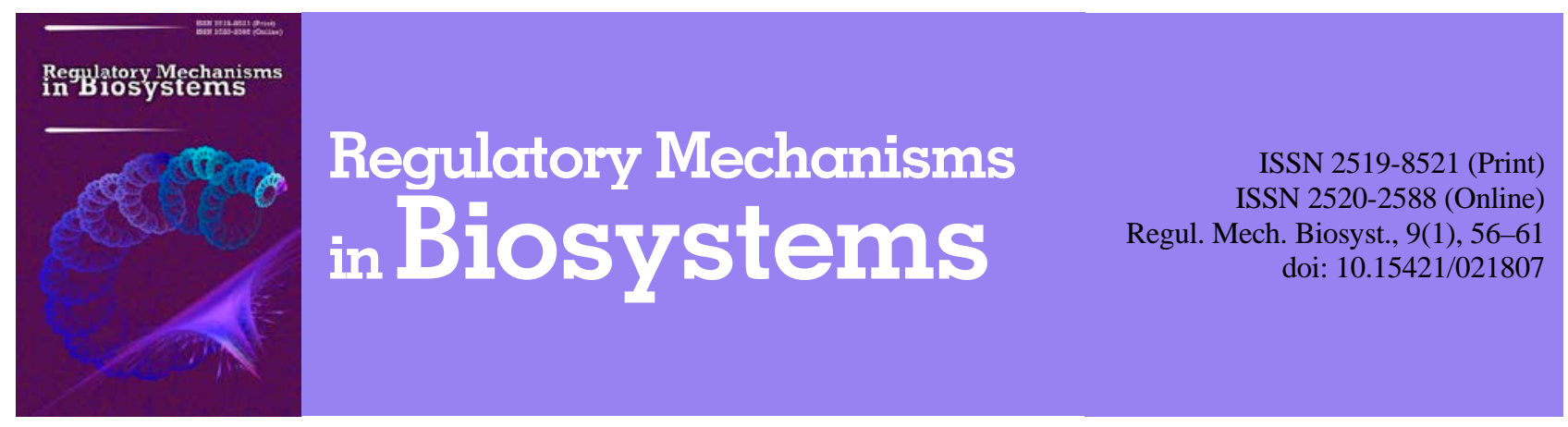

\title{
Variability of the antioxidant properties of Berberis fruits depending on the plant species and conditions of habitat
}

\author{
N. O. Khromykh*, Y. V. Lykholat*, I. M. Kovalenko**, A. M. Kabar*, O. O. Didur*, M. I. Nedzvetska* \\ *Oles Honchar Dnipro National University, Dnipro, Ukraine \\ **Sumy' National Agricultural University, Sumy, Ukraine
}

Article info

Received 14.01.2018

Received in revised form 07.02.2018

Accepted 09.02.2018

\begin{abstract}
Khromykh, N. O., Lykholat, Y. V., Kovalenko, I. M., Kabar, A. M., Didur, O. O., \& Nedzvetska, M. I. (2018). Variability of the antioxidant properties of Berberis fruits depending on the plant species and conditions of habitat. Regulatory Mechanisms in Biosystems, 9(1), 56-61. doi: 10.15421/021807
\end{abstract}

Oles Honchar Dnipro National University, Gagaryn Ave., 72, Dnipro, 49010, Ukraine. E-mail:

khromykh58@rambler.ru

Plant fruits, leaves, stems, and other parts are of high nutritional value, and are the source of physiologically active compounds, which can contribute to the treatment of many diseases caused by oxidative stress. Enrichment of the species spectrum of the fruit plants expands the possibilities of their use in dietary nutrition and human treatment. Unfortunately, the introduction of the new fruit plant species in industrial gardens in the Steppe Dnieper is limited to a large extent by the unfavorable climate. In this regard, the assessment of the possibility of realizing the genetic potential of fruit plants from different geographical areas in the steppe climate acquires both scientific and practical significance. The study was conducted on the basis of the fruit plants collection collection of the Botanical Garden of the DNU including four introduced species and one natural species from the genus Berberis. The anomalous weather conditions during the growing season of 2017 (snowfall in April followed by a drought in June) were accompanied by an earlier stage appearance of leaves, flowering and fruit ripening of all introduced plants, especially the Asian species B. amurensis and

Sumy' National Agricultural University, Kondratyeva st., 160/5, Sumy, 40021, Ukraine. $B$. koreana, compared to the native species $B$. vulgaris. In accordance with the results obtained, fresh weight of the ripe fruits of Berberis species decreased in the order of $B$. amurensis $>$ B. vulgaris $>$ B. canadensis $>B$. koreana $>$ B. $x$ declinata. The highest total phenolics content, determined in the isopropanolic fruit extracts by Folin - Ciocalteau assay, was found in the fresh ripe fruits of B. koreana (1362 $\pm 66 \mathrm{mg}$ GAE/100 g WW), followed by B. x declinata and B. vulgaris fruits ( $91 \%$ and $77 \%$ of the B. koreana phenolics content respectively). The highest total flavonoids content determined using the aluminum chloride method was revealed in the fruits of $B$. koreana ( $210 \pm 6 \mathrm{mg}$ RE/100 g FW) exceeding the content in fruits of other Berberis species by 1.1-2.1 times, while the lowest value (103 $\pm 4 \mathrm{mg}$ RE/100 g FW) was found in the fruits of $B$. amurensis. The total reducing power, determined by RP assay, varied in the range from 5.0 to $9.6 \mathrm{mg} \mathrm{AAE} / 100 \mathrm{~g} \mathrm{DW}$, and the highest levels were found in the fruits of $B$. koreana and $B$. $\mathrm{x}$ declinata (respectively, $9.6 \pm 0.6$ and $8.6 \pm 0.5 \mathrm{mg} \mathrm{AE} / 100 \mathrm{~g} \mathrm{DW}$ ) exceeding the reducing capacity of other Berberis species by $1.7-$ 1.9 times. In the fruits of genus Berberis species strong positive correlation was found between the total reducing power and the total content of phenols $(r=0.87)$, as well as between the reducing power and the total content of flavonoids $(r=0.84)$. High correlation coefficients confirm the significant contribution of the Berberis fruit phenolic compounds, including the flavonoids, to the antioxidant capacity. So, the study results showed that fruits of all examined Berberis species can be an easily accessible source of antioxidants, however, the antioxidant capacity of fruits decreased in order of B. koreana $>$ B. $\mathrm{x}$ declinata $>$ B. vulgaris $>$ B. amurensis $>$ B. canadensis.

Keywords: fruit plants; Berberis; antioxidants; phenols; flavonoids; total reducing power

\section{Introduction}

The introduction of fruit plants enriches the variety of the species composition of the regional flora and at the same time creates an opportunity to expand the vegetable raw material base to meet the nutritional needs of human health. To date, more than 400 species of fruit and berry plants have been introduced in different regions of Ukraine, but they have been introduced insufficiently in industrial gardens in the Steppe Dnieper due to the unfavorable climate. Efficiency of the adaptation of useful fruit species to the adverse regional climatic conditions can be increased, in particular, due to the use of synthetic plant growth regulators (Shcherbina et al., 2017). Recently the technogenic impact and changes of climate have affected the state of living organisms: plants (Lykholat et al., 2017), animals (Brygadyrenko, 2015) and people (Lykholat et al., 2016). Plant fruits, leaves, stems and other parts are of high nutritional value and are the source of physiologically active compounds. This predetermines their long-term use in traditional medicine and today presents a number of important objects of numerical research to obtain new substances for the creation of therapeutic agents (Bak et al., 2010; Orhan, 2012; Imenshahidi \& Hosseinzadeh, 2016; Rahimi-Madiseh et al., 2017). Thanks to the ability to biosynthesis and the accumulation of the components with antioxidant properties, fruit plants can contribute to the treatment of many diseases caused by oxidative stress (Sahan et al., 2012). For instance, the antioxidant ability of the phenolic compounds contained in plants is associated with anti-carcinogenic, anti-mutagenic and antiinflammatory effects, as well as the effect on signaling pathways of carcinogen metabolism (Huang et al., 2010). Extracts from fruits, leaves, roots and other plant organs are now widely used in medical research. In particular, the high potential of the extracts from Berberis vulgaris for inhibiting lipid peroxidation has been demonstrated, indicating promising use in the treatment of hepatic oxidative stress, idiopathic male factor infertility and Alzheimer's disease (Abd ElWahab et al., 2013). 
In the recent decades, Alzheimer's disease has become one of the most threatening diseases in the elderly, especially because of the lack of an effective therapeutic agent against this disease. According to the generally accepted cholinergic hypothesis of the origin of the disease, its appearance is associated with a deficiency of the neurotransmitters acetylcholine and butyrylcholine; consequently, the inhibition of the acetylcholinesterase and butyrylcholinesterase enzymes, that cleave acetylcholine and butyrylcholine, has become the common approach to the treatment of Alzheimer's disease (Orhan, 2012). Since the necessary properties possess metabolites of plant origin, in this regard, the establishment of a wide range of pharmacological effects of the natural alkaloids has become of great importance. In the methanol extracts from roots and stems of different plants of the Berberis genus, four alkaloids were identified by HPLC, including berbamine, jatroizine, berberine and palametin (Di et al., 2003). The most well-defined are the properties of isoquinoline alkaloid berberine, which is contained in plants of different species of the genus Berberis. The berberine effects include an inhibitory effect on acetylcholinesterase and butyrylcholinesterase, inhibition of monoamine oxidase, reduction of amidoid-peptide levels and lower cholesterol levels, making berberine a promising agent against Alzheimer's disease (Ji \& Shen, 2011).

Among all the species of Berberis genus, the phytochemical composition of $B$. vulgaris is the most widely studied at present, including a large number of components, such as ascorbic acid, vitamin $\mathrm{K}$, several triterpenoids, more than 10 phenolic compounds and more than 30 alkaloids. Thus, three phenolic compounds were identified in the extracts from root cortex of $B$. vulgaris, including $\mathrm{N}$-(p-trans-Cumaroyl) tyramine, cannabisine $\mathrm{G}$ and (+/-)-lyonirisinol; of these, cannabisin exhibits high antioxidant activity (Tomosaka et al., 2008). In addition to alkaloid berberine, the most important components of the roots, bark, leaves and fruits of $B$. vulgaris are isoquinoline alkaloids, beramines and palmatin. As a result, extracts from almost all parts of $B$. vulgaris can have anti-inflammatory, antioxidant, antidiabetic, antibacterial, analgesic and hepatotoxic effects (Imanshahidi and Hosseinzadeh, 2008).

Recent studies have confirmed the known effects of $B$. vulgaris in traditional medicine and justified the use of fruits and other organs of $B$. vulgaris for the development of new drugs (Rahimi-Madiseh et al., 2017). In particular, it has been shown that $B$. vulgaris extracts are safe and non-toxic and can induce the death of cancer cells due to their potent antioxidant activity (Abd El-Wahab et al., 2013; Hoshyar et al., 2016). In addition, based on clinical trials, the suitability of $B$. vulgaris extracts and berberine has been demonstrated as well for the treatment of tumors, diabetes, cardiovascular diseases, hyperlipidemia, inflammation, bacterial and viral infections, mental illnesses, Alzheimer's disease, osteoporosis (Imenshahidi \& Hosseinzadeh, 2016).

Other species of the Berberis genus require detailed phytochemical studies; however, data on the chemical composition of extracts from the roots of $B$. aetnensis and $B$. libanotica indicate the possibility of using these plants as promising species for the treatment of Alzheimer's disease (Bonesi et al., 2013). The analysis of methanolic extracts from the bark of $B$. darwinii for inhibition of acetylcholine esterase in vitro has confirmed the therapeutic potential of the plants for the treatment of Alzheimer's disease (Habtemariam, 2011).

The numerous studies of the plant's physiologically active compounds have shown the dependence of their accumulation both on the plant properties and on the environment (Vagiri et al., 2013). For instance, in the $B$. asiatica plants in the western Himalayas, the berberine content was significantly higher in the populations growing at low altitudes and in all populations was higher in the roots than in the stems. In addition, moisture and potassium content of the soil signifycantly affected the berberine content (Andola et al., 2010). It was shown that the total content of alkaloids in the stems and roots of different plants of the Berberis genus depends on the origin of plants, their species and various organs (Di et al., 2003). Consequently, the content of physiologically active metabolites in fruits and other parts of the plant is determined genetically and simultaneously has a high dependence on the microclimatic and edaphic conditions in which the ontogenetic development of the fruit plants took place. In this paper, we aimed to study the implementation of the genetically determined antioxidant potential of fruits of the Berberis species during vegetation in the climatic conditions of the Steppe Dnieper.

\section{Materials and methods}

Study area. The research was conducted in 2017 in Dnipro city (steppe zone of Ukraine) in the Botanical Garden of Oles Honchar Dnipro National University (48²6'14’' N, 3502'35’' E). The climate of the region has distinct continental features, including seasonal droughts with high temperatures and dry hot winds. The low average amount of precipitation $(472 \mathrm{~mm}$ ) decreases in arid years to $250 \mathrm{~mm}$, and the total evaporation for a year exceeds the amount of precipitation by $2-3$ times. The weather conditions during the period of research were characterized by abnormal features, in particular, the precipitation of $4 \mathrm{~cm}$ of snow with the simultaneous decrease in temperature to $3-6^{\circ} \mathrm{C}$ from April 19 to 22, and thereafter the heat and droughts observed during June (Table 1).

Table 1

Local weather conditions in June 2017 (city of Dnipro)

\begin{tabular}{lcccccccc}
\hline \multirow{2}{*}{ Period } & \multicolumn{3}{c}{$\begin{array}{c}\text { Air temperature, } \\
{ }^{\circ} \mathrm{C}\end{array}$} & \multicolumn{2}{c}{$\begin{array}{c}\text { Temperature on the } \\
\text { surface of the soil, }{ }^{\circ} \mathrm{C} \text { humidity, \% }\end{array}$} & \multicolumn{2}{c}{ Relative } & \multicolumn{2}{c}{ Rainfall, mm } \\
\cline { 2 - 9 } & average & norm & min & max & min & average & actual & norm \\
\hline I decade & 20.1 & 19.1 & 6.3 & 57.0 & 23 & 52 & 0.3 & 14.0 \\
II decade & 19.0 & 19.1 & 8.8 & 58.2 & 28 & 64 & 17.1 & 27.0 \\
III decade & 23.2 & 20.6 & 8.8 & 60.3 & 27 & 60 & 19.7 & 18.0 \\
\hline
\end{tabular}

Data collection. The study objects were the fruits of the Berberis plants from the collection of the Botanical Garden of DNU, among which there was a natural species $B$. vulgaris, as well as four introduced species from different geographic regions. The Berberis genus has up to 500 species of plants and belongs to the Barberry family (Berberidaceae). All plants of this genus are ornamental shrubs that are spectacular during flowering and fruiting, have smart leaves and spiny shoots. Their areas of natural growth are Transcaucasia, Southern and Eastern Europe, and Asia, where the plants prefer to settle in dry and light areas near forests, on mountain slopes, infertile soils.

B. vulgaris (European barberry) has a natural distribution within the Near East, Transcaucasia, Central, Eastern and Southern Europe, where it grows on the forest edges, slopes, lawns; in the mountains reaches up to $2000 \mathrm{~m}$. Barberry prefers light and dry areas. It is also found on chalk outcrops and river gravels. This species has shoots of up to $2-3 \mathrm{~m}$ in height, blooms in the period from April to May; the fruits ripen during September - October. The main advantage over other fruit barberries is its high winter hardiness; it is able to survive frosts down to $-35^{\circ} \mathrm{C}$.

B. amurensis is common in the Far East, Korea, and China, where it grows on the fringes of forests and the banks of mountain streams, on stony ground. This is a thorny shrub with a sprawling crown up to $3.5 \mathrm{~m}$ in height. The shoots have a yellowish tint; they turn gray-yellow by the autumn. The color of the leaves also varies depending on the season: in summer they are bright green, and in autumn red or golden-red. The fruits of this species are red, shiny, and edible, ripen in October.

B. canadensis (American barberry) grows in the valleys and on the banks of the rivers of North America, where it also grows on mountain slopes. Brown and purple shoots of the bush reach a height of 2.0 $2.5 \mathrm{~m}$. The species blooms in June, the fruits have an elliptical shape, up to $1 \mathrm{~cm}$ long. This species bloomsis abundantly from mid-May to June, unpretentious, easily tolerates drought and winter frosts. This species has sufficient winter hardiness and heat resistance, but suffers from dryness.

B. koreana grows on the Korean peninsula. This species has became known as a cultivar only relatively recently, at the beginning of the 20th century, and has not yet widely spread. The height of the shrub does not exceed $2 \mathrm{~m}$, the leaves are larger, stiffer, almost leathery. This plant blooms from late May to the second decade of June, approximately in the course of two weeks. Fruits ripen in September and have an almost spherical shape. This species is characterized by high winter hardiness; it prefers light, but it tolerates a partial shade, it is not exacting to the fertility of soils, it is drought-resistant. This species prefers alkaline soils, although it also grows on slightly acidic soils, but it does not survive the stagnant moistening and compaction of soils. 
B. $\mathrm{x}$ declinata is a hybridogenic species, which is a spontaneous hybrid of $B$. canadensis and $B$. vulgaris. This is a shrub of up to $2 \mathrm{~m}$ in height with a densely curved crown, which has spines up to $1.5 \mathrm{~cm}$ in length. Plant leaves appear in April, flowering begins at the end of May and continues in June. Fruits up to $1 \mathrm{~cm}$ in length ripen during AugustSeptember. This species is one of the most winter-hardy species and can withstand frost up to $-34{ }^{\circ} \mathrm{C}$. The plants of this species do not require watering, however they need intensive lighting. The observations conducted during 2017 characterized the phenological peculiarities of the studied species of the genus Berberis, so the selection of fruits is carried out in accordance with the terms of their maturation for the different plant species (Table 2).

Table 2

Characteristics of the phenological differences of genus Berberis species in 2017

\begin{tabular}{|c|c|c|c|c|c|}
\hline \multirow{2}{*}{ Species } & \multirow{2}{*}{ Introduction time } & \multirow{2}{*}{ Source of the introduction } & \multicolumn{3}{|c|}{ Phenological phases of plants } \\
\hline & & & leaves appearance & flowering & ripe fruit appearance \\
\hline B. vulgaris L. & 1954 & M.M. Gryshko NBG, Ukraine, Kyiv & 10.04 & $27.04-07.05$ & 28.09 \\
\hline B. amurensis Rupr. & 1956 & Finland, Helsinki & 03.04 . & $20.04-02.05$ & 16.09 . \\
\hline B. canadensis Mill. & 1952 & Canada, Ottawa & 06.04. & 25.04. -05.05 . & 25.09. \\
\hline B. koreana Palib. & 1950 & Denmark, Copenhagen & 05.04. & 21.04. - 02.05. & 19.09. \\
\hline B. x declinata Schrad. & 1950 & State Nykytskyj Botanical Garden, Crimea, Yalta & 08.04 . & 25.04. - 04.05. & 26.09 . \\
\hline
\end{tabular}

It should be noted that in April 2017 anomalous snowfall together with a sharp drop in temperature coincided with the flowering phase in the two studied species B. amurensis and B. koreana, and these species were the first to form ripe fruit. All other species started the flowering phase later, after the temperature had risen. The strong drought, which was observed in the first two decades of June, created unfavorable conditions for plants of all the species in the initial period of fruit formation.

Data analysis. The antioxidant compounds of fruits of all Berberis species were extracted using $80 \%$ isopropanol. The extracts intended to determine the total content of phenolic compounds and flavonoids were obtained by boiling $1 \mathrm{~g}$ of pulp of fresh fruits (without peel and seeds) in $10 \mathrm{ml}$ of isopropanol for 1 hour with a reflux condenser. After this, the crude extracts were cooled, filtered, and then the volume of isopropanol was adjusted to $10 \mathrm{ml}$. To determine the total antioxidant capacity (by FRAP assay) of the fruits, extracts obtained by holding the air-dried powdered vegetable material $(200 \mathrm{mg})$ in $5 \mathrm{ml}$ of isopropanol for 24 hours at room temperature were used.

The total phenolic content of the fruit extracts was measured by the Folin - Ciocalteau method described by Singleton et al (1999) in modification (Nwanna et al., 2013). Briefly, $0.2 \mathrm{ml}$ of the plant extract diluted with $0.2 \mathrm{ml}$ of distilled water was oxidized with $1 \mathrm{ml}$ of $10 \%$ Folin Ciocalteau reagent, and neutralized by $0.8 \mathrm{ml}$ of $7.5 \%$ sodium carbonate solution in three minutes. Next, the reaction mixture was incubated for 40 minutes at $45^{\circ} \mathrm{C}$, and cooled, after which the optical density of the samples was measured at a wavelength of $726 \mathrm{~nm}$. The total content of the phenolic compounds was calculated using a calibration graph prepared on the solutions of Gallic acid (GA) in the range 2.5-20.0 $\mu \mathrm{g} / \mathrm{ml}$. The study results were expressed as mg Gallic acid equivalents per $100 \mathrm{~g}$ of fruit wet weight (mg GAE/100 $\mathrm{g} \mathrm{WW}$ ).

Aluminium chloride spectrophetometric method in the modification of Pękal and Pyrzynska (2014) was used for the measurement of the total flavonoids content in the Berberis fruits. In brief, to $2 \mathrm{ml}$ of isopropanol extract from the fresh fruits, $1 \mathrm{ml}$ of a $2 \%$ solution of aluminum chloride $\left(\mathrm{AlCl}_{3}\right)$, and $1 \mathrm{ml}$ of $1 \mathrm{M}$ sodium acetate solution were added. The reaction mixture was maintained for 10 minutes at room temperature, filtered and the optical density measured at $425 \mathrm{~nm}$. The quantitative content of flavonoids in the samples was calculated using a calibration graph prepared on the routine solutions with different concentrations (7.5, 15, 30, 50, 75, and $90 \mu \mathrm{g} / \mathrm{ml})$, and the result was expressed as $\mathrm{mg}$ routine equivalents per $100 \mathrm{~g}$ of fruit wet weight (RE/100 $\mathrm{g} \mathrm{WW}$ ).

The reducing power (RP) of the Berberis fruits was determined according to the procedure described by Pulido et al. (2000). Briefly, 1 $\mathrm{ml}$ of extract was mixed with $1 \mathrm{ml}$ of a $0.2 \mathrm{M}$ sodium phosphate buffer ( $\mathrm{pH}=6.6)$ and $1 \mathrm{ml}$ of $1 \%$ potassium ferricyanide $\left(\mathrm{K}_{3} \mathrm{Fe}(\mathrm{CN})_{6}\right)$, and the reactive mixture was incubated at $50^{\circ} \mathrm{C}$ for $20 \mathrm{~min}$. After that, $1 \mathrm{ml}$ of $10 \%$ trichloroacetic acid was added to the mixture which was centrifuged at $3000 \mathrm{rpm}$ for $10 \mathrm{~min}$. Then, to $1 \mathrm{ml}$ of the supernatant $1 \mathrm{ml}$ distilled water and $0.2 \mathrm{ml}$ of $0.1 \%$ ferric chloride $\left(\mathrm{FeCl}_{3}\right)$ solution were added, and the absorbance was measured at $700 \mathrm{~nm}$. Ascorbic acid was used as reference standard, and the calibration graph was constructed by solutions of ascorbic acid (AA) in the range of concentrations 10 $100 \mu \mathrm{g} / \mathrm{ml}$. The total reduction power of the crude fruit extracts was expressed as ascorbic acid equivalents per $\mathrm{g}$ of dry fruits weight (mg
$\mathrm{AAE} / \mathrm{g} \mathrm{DW}$ ) in accordance with the method of Augustus et al (2015).

Data were expressed as mean \pm standard deviation (SD) of three measurements. The differences were considered to be statistically significant at $\mathrm{P}<0.05$. Statistical analyses were performed with used T-test and F-test for independent samples. Interspecific differences in the antioxidant properties of the Berberis fruits were evaluated in comparison with the indices of the natural species $B$. vulgaris. Pearson correlation was used to analyze the relation between environmental variables of Berberis pooled for all sampling dates.

\section{Results}

The average mass of raw ripe fruits of the different species of Berberis measured at the time of ripe fruit selection varied considerably in the different species of the genus (Table 3).

Table 3

The weight of the fresh Berberis fruits (average of 100 fruits) collected in 2017

\begin{tabular}{lcc}
\hline \multicolumn{1}{c}{ Species } & Fruit weight, $\mathrm{g}, \mathrm{x} \pm \mathrm{SD}$ & $\mathrm{P}$ \\
\hline B. vulgaris & $24.99 \pm 8.374$ & - \\
B. amurensis & $39.45 \pm 6.050$ & 0.0001 \\
B. canadensis & $19.09 \pm 3.356$ & 0.0171 \\
B. koreana & $16.58 \pm 1.394$ & 0.0007 \\
B. $x$ declinata & $11.66 \pm 1.643$ & $<0.0001$ \\
\hline
\end{tabular}

A comparative analysis of fruit fresh weight of the introduced species with the weight of $B$. vulgaris fruits showed a significant $(\mathrm{P}<$ 0.05 ) difference in the characteristics. The greatest average weight was found for the fruits of $B$. amurensis ( $39.45 \pm 2.211$ g per 100 fruits), and the smallest weight was found for the fruits of the hybrid species $B . \mathrm{x}$ declinata (11.22 $\pm 1.076 \mathrm{~g}$ per 100 fruits).

The total phenolic compounds in the ripe fruits of the different Berberis species as determined by Folin - Ciocalteau assay, was expressed as Gallic acid equivalents (GAE) by reference to a standard curve (y $=304.15 \mathrm{x}$, and $\mathrm{R}^{2}=0.99$ ). The total flavonoids content of various species of Berberis was determined using aluminum chloride method, and is expressed as routine equivalent (equation of regression $\mathrm{y}=$ $0.0139 x, R^{2}=0.999$ ). The total reducing power (RP) of the fruits of Berberis different species was expressed as the equivalent of ascorbic acid (equation of linear regression $y=252.05 x-32.316, R^{2}=0.993$ ). Then, the study results (mean \pm standard deviation) were statistically processed using the $B$. vulgaris indexes as a control (Table 4).

\section{Discussion}

In accordance with the results obtained, average fruit weight of the different Berberis species decreased in the order of $B$. amurensis $>$ B. vulgaris $>B$. canadensis $>B$. koreana $>B$. $\mathrm{x}$ declinata. The size and weight of the fruits is a specific feature of a certain genotype, as well as important attributes of fruit quality, which, along with other characteristics, help to correctly evaluate new or introduced species (McGhie et al., 2005; Kaldmae et al., 2013). The weight of the B. amurensis fruits exceeded the weight of the fruits of all other Berberis species by 1.6-3.4 
times, which can be advantage of this species at the estimation of fruit harvest. In addition, $B$. amurensis was the first of all the species to undergo the flowering and ripening of the fruits in less favorable conditions in 2017 (Table 2).

\section{Table 4}

Statistical estimate of total phenolic, total flavonoids content, and the reducing power of the Berberis fruits

\begin{tabular}{|c|c|c|c|c|c|c|}
\hline Species & Index, $\mathrm{x} \pm$ SD & t-value & $\mathrm{df}$ & $\mathrm{P}$ & F-ratio & $\mathrm{P}$ \\
\hline & \multicolumn{6}{|c|}{ Total phenolic content (mg Gallic Acid Equivalents/100 g WW) } \\
\hline B. vulgaris & $1052.3 \pm 54.34$ & - & - & - & - & - \\
\hline B. amurensis & & 3.15 & 4 & 0.0347 & 1.40 & 0.833 \\
\hline B. canadensis & $899.2 \pm$ & 4.14 & 4 & 0.0144 & 2.56 & 0.562 \\
\hline B. koreana & 1362.8 & -6.28 & 4 & 0.0033 & 1.48 & 0.806 \\
\hline \multirow[t]{2}{*}{ B. x declinata } & $1243.2 \pm 27.43$ & -5.43 & 4 & 0.0056 & 3.92 & 0.406 \\
\hline & \multicolumn{6}{|c|}{ Total flavonoids content (mg Routine Equivalents/100 g WW) } \\
\hline B. vulgaris & $142.5 \pm 6.38$ & - & - & - & - & - \\
\hline B. amure & & 9.04 & 4 & 0.0008 & 2.39 & 0.590 \\
\hline B. can & 109 & 7.06 & 4 & 0.0021 & 1.73 & 0.734 \\
\hline B. koreana & $210.4 \pm$ & -13.31 & 4 & 0.0002 & 1.09 & 0.955 \\
\hline \multirow[t]{2}{*}{ B. x declinata } & $188.2 \pm 7.83$ & -7.84 & 4 & 0.0014 & 1.50 & 0.799 \\
\hline & \multicolumn{6}{|c|}{ Total reducing power (mg Ascorbic Acid Equivalents/g DW) } \\
\hline B. vulgaris & & - & - & - & - & - \\
\hline B. amurensis & & & 4 & & 1.93 & 0.683 \\
\hline B. canadensis & $5.0 \pm 0.41$ & -8.03 & 4 & 0.0013 & 1.45 & 0.815 \\
\hline B. koreana & $9.6 \pm 0.5$ & 5.08 & 4 & 0.0071 & 2.10 & 0.646 \\
\hline B. x declinata & $8.6 \pm 0.50$ & 2.59 & 4 & 0.0607 & 1.69 & 0.744 \\
\hline
\end{tabular}

In our study, the total phenolic content of the crude extracts of the Berberis fruits varied in a relatively wide range, and the content of the phenols in the $B$. vulgaris was significantly $(\mathrm{P}<0.05)$ different from those of all other species (Table 4). The study results showed that the highest phenolics concentration was revealed in the fresh ripe fruits of B. koreana (1362.8 $\pm 66.1 \mathrm{mg}$ GAE/100 g WW), followed by $B$. $\mathrm{x}$ declinata fruits ( $91 \%$ of the $B$. koreana phenolics content). The phenolics concentration in the fruits of the native species $B$. vulgaris (1052.3 $\pm 54.3 \mathrm{mg}$ GAE/100 g WW) reached 77\% of the highest content in B. koreana fruits. Similar content of the polyphenols was found by Pyrkosz-Biardzka et al. (2014) in the methanolic crude extracts of $B$. vulgaris fruits, where it reached $1024.3 \pm 15.2 \mathrm{mg}$ GAE/100 g FM. The aqueous and alcoholic extracts of $B$. vulgaris fruits contained the total phenols at the levels $184.1 \pm 5.3$ and $291.2 \pm 2.5 \mathrm{mg} \mathrm{GAE} / \mathrm{g}$ of dried extract respectively (Hoshyar et al., 2016). In total, the results obtained showed the fairly high total phenolic content in the fruits of Berberis species compared to other fruit plants. Thus, Wolfe et al. (2003) evaluated the highest total phenolic content in different varieties of apples as $589 \pm 83.2$ and $500 \pm 13.7 \mathrm{mg} \mathrm{GAE} / 100 \mathrm{~g}$ of crude mass.

The smallest value of the phenolic compounds was revealed in the fresh fruits of the northern species $B$. canadensis $(899.2 \pm 34.0 \mathrm{mg}$ GAE/100 g WW), and it was one and a half times lower than that of the southern species $B$. koreana. Significant differences in the content of phenolic compounds in the investigated fruits of Berberis species are consistent with other data on the variation of total phenolic content, depending on the genotype and plant tissues as well. Thus, a study of small fruits from 107 genotypes of three genera (Vaccinium L., Rubus L., and Ribes L.) demonstrates the wide diversity of phytochemical levels (total phenols and anthocyanins), and antioxidant capacities within and across genera (Moyer et al., 2002). The variation in the content of polyphenols in the range from 523 to $2724 \mathrm{mg}$ GAE/100 g dry mass was found in a group of 67 different apple varieties (Wojdyło et al., 2008). In the leaves and flowers of Crataegus azarolus the total content of the phenols varied from $2.83 \mathrm{mg}$ to $111.96 \mathrm{GAE} / \mathrm{g}$ of dried extract (Lakache et al., 2016). The HPLC analysis showed that among four cultivars of saskatoon berry (Amelanchier alnifolia Nutt.) grown in Finland, the total phenolic content varied $410.6-822.1 \mathrm{mg} / \mathrm{g}$ FW (Lavola et al., 2016). The total level of the polyphenols of four different honeysuckle (Lonicera caerulea L.) genotypes identified by LC/MS method was 775-2005 mg/100 g dry matter (Wojdyło et al., 2013).

The natural phenolic compounds are the secondary plant metabolites, which form a large and diverse group of the phytochemicals including simple phenols, lignans, phenylpropanoids, flavonoids, coumarins and other compounds (Jafari et al., 2014). Phenols carry out important physiological functions in the plant organism, in particular, increased accumulation of phenolic compounds in the leaves positively correlated with the improvement of the stability of the clover plants to drought (Nichols et al., 2015). Flavonoids are polyphenolic compounds, whose potential is not fully revealed, although they have been studied for a long time (Eghdami \& Sadeghi, 2010). In our study, the highest total content of the flavonoid compounds revealed in fruits of $B$. koreana (210.4 $\pm 6.1 \mathrm{mg}$ RE/100 g WW) exceeded the content in fruits of other Berberis species by 1.1-2.1 times, and the lowest value (102.8 $\pm 4.1 \mathrm{mg}$ $\mathrm{RE} / 100 \mathrm{~g} \mathrm{WW}$ ) was found in the fruits of $B$. amurensis (Table 4). The content of flavonoids determined by us in the isopropanolic extracts of $B$. vulgaris fruits (142.9 $\pm 6.4 \mathrm{mg} \mathrm{RE} / 100 \mathrm{~g} \mathrm{WW})$ was higher than the content in methanol extract $(86.0 \pm 1.8 \mathrm{mg} R E / 100 \mathrm{~g}$ FM), reported by Pyrkosz-Biardzka et al. (2014). The highest flavonoids share in total phenolics content was found in the fruits of B. koreana and B. x declinata $(15.5 \%$ and $15.1 \%$ respectively), while it decreased to $13.6 \%$, $12.5 \%$, and $11.1 \%$, respectively, in the fruits of species $B$. vulgaris, $B$. canadensis and B. amurensis. Much higher percentages of flavonoids were revealed in the fruits of different apple genotypes, where the flavonoids accounted for $52-60 \%$ (Wolfe et al., 2003), or even $80 \%$ of the total content of phenols (Wojdyło et al., 2008). The highest amount of flavonoids in the leaves and flowers of Crataegus azarolus reached $5.9 \mathrm{mg}$ QE/g of dried extract (Lakache et al., 2016).

The reducing power reflects the antioxidant capacity of plant extracts, and it can be characterized by different methods and expressed in different units, which complicates comparison of results. The antioxidant properties of fruits are due to both the ability to trap free radicals and to form metal chelates (Brewer, 2011), which suggests differences in the estimation of the reduction potential. In our study, the highest levels of the total reducing power (determined by RP assay) was found in the fruits of $B$. koreana and $B$. x declinata (respectively, $9.6 \pm$ 0.6 and $8.6 \pm 0.5 \mathrm{mg} \mathrm{AE} / 100 \mathrm{~g} \mathrm{DW}$ ) exceeding the indices of other species by 1.7-1.9 times (Table 4). Deepa et al. (2013) reported the total reducing power of the methanolic extracts of different Indian spice herbs variation in range $0.57-6.0 \mathrm{mg} \mathrm{AAE} / \mathrm{g} \mathrm{DW}$. In the fruits of two different genotypes of eggplant (Solanaceae) the reducing power was determined at the levels $48.8 \pm 0.6$ and $56.7 \pm 1.4 \mathrm{mg} \mathrm{AE} / \mathrm{g}$ of dried extract (Nwanna et al., 2013). The reducing power of fresh Thymus vulgaris leave extracts varied between 0.39-0.94 mg AAE/g WW (Eghdami et al., 2013). The reducing capacity of the extracts from the plants of Cyperus erectus in the range 5.6-20.0 mg AAE/g DW was estimated as high (Augustus et al., 2015). Therefore, the reducing power of the Berberis fruits defined in the range 5.0-9.6 mg AAE/100 g DW may be deemed sufficiently high. Since the flavonoids are the major contributors to the total reducing power in different fruit species (Borges et al., 2010), it is possible that antioxidant capacity of fruits of some Berberis species could be reduced due to the adverse effects of abnormal weather conditions during the growing season in 2017 (Table 2). This assumption is consistent, in particular, with the data of Bettaieb et al. (2011) on the dependence of the antioxidant level of cumin (Cuminum cyminum L.) on the power of stress in experimental drought conditions.

In our study,a strong positive correlation was found between the total reducing power and the total content of phenols in the fruit extracts of Berberis species ( $\mathrm{r}=0.87, \mathrm{P}<0.001$ ), and the total content of flavonoids and the total reducing power as well $(r=0.84, \mathrm{P}<0.001)$. High correlation coefficients confirm the significant contribution of phenolic compounds, including flavonoids, to the antioxidant capacity of the fruits of all examined Berberis species, which can be an easily accessible source of antioxidants. The obtained results comport with data (Koncić et al., 2010) on the correlation between the antioxidant capacity and phenolic compounds content in fruits of B. vulgaris and B. croatica.

\section{Conclusion}

The study results confirmed the remarkable effect of genotype on the nature of phenology and accumulation of the phenolic compounds in the fruits of different Berberis species. Regional unfavorable weather 
conditions during the growing season stimulated the earlier stage appearance of leaves, flowering and fruit ripening of all introduced plants compared to the native species $B$. vulgaris. However, the most accelerated were the phenological rhythms of the Asian species B. amurensis and B. koreana, while the phenological phases of the northern species $B$. canadensis and the hybrid species $B . \mathrm{x}$ declinata were closer to $B$. vulgaris. The fruit weight of the different Berberis species decreased in the order of $B$. amurensis $>B$. vulgaris $>B$. canadensis $>B$. koreana $>B$. x declinata. Antioxidant capacity was determined as relatively high in the fruits of all Berberis species, with a significant predominance of B. koreana and B. x declinata. The total phenolic content of the fruits and also the total reducing power decreased in the order of $B$. koreana $>B$. $\mathrm{x}$ declinata $>B$. vulgaris $>B$. amurensis $>B$. canadensis, while the total flavonoids content - in the order of B. koreana $>B$. x declinata $>B$. vulgaris $>B$. canadensis $>B$. amurensis. The relatively low concentration of the antioxidants in the fruits of $B$. amurensis can be compensated for by the largest fruit weight of this species. Results showed that all the studied species of the genus Berberis are sufficiently rich sources of natural phenolic antioxidants. Species B. koreana and B. x declinata could potentially be the most promising in the unstable climatic conditions of the Steppe Dnieper.

\section{References}

Abd El-Wahab, A. E., Ghareeb, D. A., Sarhan, E. E. M., Abu-Serie, M. M., \& El Demellawy, M. A. (2013). In vitro biological assessment of Berberis vulgaris and its active constituent, berberine: antioxidants, anti-acetylcholinesterase, anti-diabetic and anticancer effects. BMC Complementary and Alternative Medicine, 13, 218.

Andola, H. C., Gaira, K. S., Rawal, R. S., Rawat, M. S., \& Bhatt, I. D. (2010). Habitat-dependent variations in berberine content of Berberis asiatica Roxb. ex. DC. in Kumaon, Westem Himalaya. Chemistry and Biodiversity, 7(2), 415-420.

Augustus, O. K., Janet, J. O., Ebenezer, T. B., \& Ogboma, U. J. (2015). Antioxidant activities, total flavonoid and total phenolic contents of whole plant of Kyllinga erecta Shumach. Journal of Food and Nutrition Research, 3(8), 489-494.

Bak, I., Lekli, I., Juhasz, B., Varga, E., Varga, B., Gesztelyi, R., Szendrei, L., \& Tosaki, A. (2010). Isolation and analysis of bioactive constituents of sour cherry (Prunus cerasus) seed kernel: An emerging functional food. Journal of Medicinal Food, 13(4), 905-910.

Bettaieb, I., Knioua, S., Hamrouni, I., Limam, F., \& Marzouk, B. (2011). Waterdeficit impact on fatty acid and essential oil composition and antioxidant activities of cumin (Cuminum cyminum L.) aerial parts. Journal of Agricultural and Food Chemistry, 59(1), 328-334.

Bonesi, M., Loizzo, M. R., Conforti, F., Passalacqua, N. G., Saab, A., Menichini, F., \& Tundis, R. (2013). Berberis aetnensis and B. libanotica: A comparative study on the chemical composition, inhibitory effect on key enzymes linked to Alzheimer's disease and antioxidant activity. Joumal of Pharmacy and Pharmacology, 65(12), 1726-1735.

Borges, G., Degeneve, A., Mullen, W., \& Crozier, A. (2010). Identification of Flavonoid and phenolic antioxidants in black currants, blueberries, raspberries, red currants, and cranberries. Journal of Agricultural and Food Chemistry, 58(7), 3901-3909.

Brewer, M. S. (2011). Natural antioxidants: Sources, compounds, mechanisms of action, and potential applications. Comprehensive Reviews in Food Science and Food Safety, 10, 221-247.

Brygadyrenko, V. V. (2015). Community structure of litter invertebrates of forest belt ecosystems in the Ukrainian Steppe Zone. International Journal of Environmental Research, 9(4), 1183-1192.

Deepa, G., Ayesha, S., Nishtha, K., \& Thankamani, M. (2013). Comparative evaluation of various total antioxidant capacity assays applied to phytochemical compounds of Indian culinary spice. International Food Research Journal, 20(4), 1711-1716.

Di, D. L., Liu, Y. W., Ma, Z. G., \& Jiang, S. X. (2003). Determination of four alkaloids in Berberis plants by HPLC. Zhongguo Zhong Yao Za Zhi, 28(12), 1132-1134 (in Chinese).

Eghdami, A., Eizadi, M., \& Sadeghi, F. (2013). Polyphenolic content and antioxidant activity of hydroalcohlic and alcoholic extract of Thymus vulgaris. Journal of Biodiversity and Environmental Sciences, 3(5), 94-101.

Eghdami, A., \& Sadeghi, F. (2010). Determination of total phenolic and flavonoids contents in methanolic and aqueous extract of Achillea millefolium. The Journal of Organic Chemistry, 2, 81-84.
Habtemariam, S. (2011). The therapeutic potential of Berberis darwinii stem-bark: Quantification of berberine and in vitro evidence for Alzheimer's disease therapy. Natural Product Communications, 6(8), 1089-1090.

Hoshyar, R., Mahboob, Z., \& Zarban, A. (2016). The antioxidant and chemical properties of Berberis vulgaris and its cytotoxic effect on human breast carcinoma cells. Cytotechnology, 68, 1207-1213.

Huang, W. Y., Cai, Y. Z., \& Zhang, Y. (2010). Natural phenolic compounds from medicinal herbs and dietary plants: Potential use for cancer prevention. Nutrition and Cancer, 62(1), 1-20.

Imanshahidi, M., \& Hosseinzadeh, H. (2008). Pharmacological and therapeutic effects of Berberis vulgaris and its active constituent, berberine. Phytotherapy Research, 22(8), 999-1012.

Imenshahidi, M., \& Hosseinzadeh, H. (2016). Berberis vulgaris and berberine: An update review. Phytotherapy Research, 30(11), 1745-1764.

Jafari, S., Saeidnia, S., \& Abdollahi, M. (2014). Role of natural phenolic compounds in cancer chemoprevention via regulation of the cell cycle. Current Pharmaceutical Biotechnology, 15(4), 409-421.

Ji, H. F., \& Shen, L. (2011). Berberine: A potential multipotent natural product to combat Alzheimer's disease. Molecules, 16(8), 6732-6740.

Kaldmae, H., Kikas, A., Arus, L., \& Libek, A.-V. (2013). Genotype and microclimate conditions influence ripening pattern and quality of blackcurrant (Ribes nigrum L.) fruit. Zemdirbyste-Agriculture, 100(2), 167-174.

Koncić, Z. M., Kremer, D., Karlović, K., \& Kosalec, I. (2010). Evaluation of antioxidant activities and phenolic content of Berberis vulgaris L. and Berberis croatica Horvat. Food and Chemical Toxicology, 48(8-9), 2176-2180.

Kul'bachko, Y., Loza, I., Pakhomov, O., \& Didur, O. (2011). The zooecological remediation of technogen faulted soil in the industrial region of the Ukraine steppe zone. In: Behnassi, M., Shahid, S., \& D’Silva, J. (Eds.). Sustainable agricultural development. Springer, Dordrecht.

Lakache, Z., Tigrine-Kordjani, N., Tigrine, C., Aliboudhar, H., \& Kameli, A. (2016). Phytochemical screening and antioxidant properties of methanolic extract and different fractions of Crataegus azarolus leaves and flowers from Algeria. International Food Research Journal, 23(4), 1576-1583.

Lavola, A., Karjalainen, R., \& Julkunen-Tiitto, R. (2012). Bioactive polyphenols in leaves, stems, and berries of saskatoon (Amelanchier alnifolia Nutt.) cultivars. Journal of Agricultural and Food Chemistry, 60, 1020-1027.

Lykholat, T., Lykholat, O., \& Antonyuk, S. (2016). Immunohistochemical and biochemical analysis of mammary gland tumours of different age patients. Cytology and Genetics, 50(1), 32-41.

Lykholat, Y. V., Khromykh, N. A., Ivan'ko, I. A., Matyukha, V. L., Kravets, S. S., Didur, O. O., Alexeyeva, A. A., \& Shupranova, L. V. (2017). Otsinka i prohnoz invaziinosti deiakykh adventyvnykh roslyn za vplyvu klimatychnykh zmin u Stepovomu Prydniprov'i [Assessment and prediction of the invasiveness of some alien plants in conditions of climate change in the steppe Dnieper region]. Biosystems Diversity, 25(1), 52-59.

McGhie, T. K., Hunt, M., \& Barnett, L. E. (2005). Cultivar and growing region determine the antioxidant polyphenolic concentration and composition of apples grown in New Zealand. Journal of Agricultural and Food Chemistry, 53(8), 3065-3070.

Moyer, R. A., Hummer, K. E., Finn, C. E., Frei, B., \& Wrolstad, R. E. (2002). Anthocyanins, phenolics, and antioxidant capacity in diverse small fruits: Vaccinium, Rubus, and Ribes. Journal of Agricultural and Food Chemistry, 50(3), 519-525.

Nichols, S. N., Hofmann, R. W., \& Williams, W. M. (2015). Functional roles of secondary metabolites in plant-environment interactions. Physiological drought resistance and accumulation of leaf phenolics in white clover interspecific hybrids. Environmental and Experimental Botany, 119, 40-47.

Nwanna, E. E., Ibukun, E. O., \& Oboh, G. (2013). Inhibitory effects of methanolic extracts of two eggplant species from South-Western Nigeria on starch hydrolysing enzymes linked to type-2 diabetes. African Journal of Pharmacy and Pharmacology. 7(23), 1575-1584.

Orhan, I. E. (2012). Current concepts on selected plant secondary metabolites with promising inhibitory effects against enzymes linked to Alzheimer's disease. Current Medicinal Chemistry, 19(14), 2252-2261.

Pękal, A., \& Pyrzynska, K. (2014). Evaluation of aluminium complexation reaction for flavonoid content assay. Food Analytical Methods, 7, 1776-1782.

Pulido, R., Bravo, R. L., \& Saura-Calixto, F. (2000). Antioxidant activity of dietary polyphenols as determined by a modified ferric reducing/antioxidant power assay. Journal of Agricultural and Food Chemistry, 48, 3396-3402.

Pyrkosz-Biardzka, K., Kucharska, A. Z., Sokół-Łętowska, A., Strugała, P., \& Gabrielska, J. (2014). A comprehensive study on antioxidant properties of crude extracts from fruits of Berberis vulgaris L., Cornus mas L. and Mahonia aquifolium Nutt. Polish Journal of Food and Nutrition Sciences, 64(2), 91-99.

Rahimi-Madiseh, M., Lorigoini, Z., Zamani-Gharaghoshi, H., \& Rafieian-Kopaei, M. (2017). Berberis vulgaris: Specifications and traditional uses. Iranian Journal of Basic Medical Sciences, 20, 569-587. 
Sahan, Y., Cansev, A., Celik, G., \& Cinar, A. (2012). Determination of various chemical properties, total phenolic content, antioxidant capacity and organic acids in Laurocerasus officinalis fruits. Acta Horticulturae, 939, 359-366.

Shcherbyna, R. O., Danilchenko, D. M., Parchenko, V. V., Panasenko, O. I. Knysh, E. H., Hromyh, N. A., \& Lyholat, Y. V. (2017). Study of 2-((5-R-4R1-4h-1,2,4-Triazole-3-YI0Thio)acetic acid salts on growth and progress of blackberries (Kiowa variety) propagules. Research Journal of Pharmaceutical, Biological and Chemical Sciences, 8(3), 975-979.

Singleton, V. L., Orthofer, R., \& Lamuela-Raventos, R. M. (1999). Analysis of total phenols and other oxidation substrates and antioxidants by means of Folin-Ciocalteau reagent. Methods in Enzymology, 299, 152-178.

Tomosaka, H., Chin, Y. W., Salim, A. A., Keller, W. J., Chai, H., \& Kinghorn, A. D. (2008). Antioxidant and cytoprotective compounds from Berberis vulgaris (barberry). Phytotherapy Research, 22(7), 979-981.
Vagiri, M., Ekholm, A., Öberg, E., Johansson, E., Andersson, S. C., \& Rumpunen, K. (2013). Phenols and ascorbic acid in black currants (Ribes nigrum L.): Variation due to genotype, location, and year. Journal of Agricultural and Food Chemistry, 61(39), 9298-9306.

Wojdyło, A., Jáuregui, P. N. N., Carbonell-Barrachina, A. A., Oszmiański, J., \& Golis, T. (2013). Variability of phytochemical properties and content of bioactive compounds in Lonicera caerulea L. var. kamtschatica Berries. Journal of Agricultural and Food Chemistry, 61(49), 12072-12084.

Wojdyło, A., Oszmiański, J., \& Laskowski, P. (2008). Polyphenolic compounds and antioxidant activity of new and old apple varieties. Journal of Agricultural and Food Chemistry, 56(15), 6520-6530.

Wolfe, K., Wu, X., \& Liu, R. H. (2003). Antioxidant activity of apple peels. Journal of Agricultural and Food Chemistry, 51(3), 609-614. 